\title{
Quality Assessment in the Logistics of Rail Passenger Transport
}

\author{
Milan Dedík ${ }^{1, *}$, Jozef Gašparík ${ }^{1}$, and Zdenka Záhumenská ${ }^{1}$ \\ ${ }^{1}$ University of Žilina, Faculty of Operation and Economics of Transport and Communications, \\ Department of Railway Transport, Univerzitná 8215/1, 01026 Žilina, Slovakia
}

\begin{abstract}
The article is focused on analysis and rating of the quality in the passenger railway transport logistics. At first is described the relationships between logistics and transport, logistical demands for transport and functions of logistics in rail transport. In the third chapter is explained quality assessment including the description of the quality indicators in passenger rail transport and making a proposal of the new methodology for this rating. Consequently this methodology is tested for chosen transport route and is concerned with monitoring quality of the transport routes in the railway network.
\end{abstract}

\section{Introduction}

The relationship between logistics and transport is very narrow as transport ensures the physical relocation of the product from the place of production to the point of consumption. Transport is a significant factor in time benefit, it is the carrier of speed and reliability of product relocation, it is one of the most important elements of the logistical system. In the logistical chain from material supplier to customer, it is a very important and irreplaceable place $[1,2]$.

When choosing the optimum kind of transport and the mode of transport, it is very important to take into account, in particular, the type and characteristics of the goods to be transported, the method of packing, the volume, the weight, the legislative rules and other conditions. In this selection, account must be taken of the characteristics of the various modes of transport:

1. Ability to maximize transport safety, including the elimination of shocks and possible damage to the goods.

2. Ability to transport networks, the ability to provide traffic to any destination.

3. Ability to transport any quantity of materials and goods.

4. Ability to provide the optimal degree of time security and reliability.

5. Ability to ensure the optimal level of home-to-house speed.

6. Ability to provide the maximum degree of comfort

7. Ability to minimize the cost of shipping

\footnotetext{
* Corresponding author: milan.dedik@,fpedas.uniza.sk
} 
Several types of conventional and unconventional transport can be used to implement transport services. Each type has some advantages and disadvantages and has an important place in the transport system.

Conventional modes of transport are:

- railway transport

- road transport

- water transport

- air transport

Unconventional modes of transport include, for example, pipeline transport, cableways and so on [3-6].

\section{Functions of logistics in rail transport}

Rail transport is by no means a guarantee of such high-quality availability, manoeuvrability and flexibility as road transport, but in logistics, its function is very important. It can provide transport in much larger quantities, in the case of freight transport offers the possibility to transport also heavy loads, shipments with specific properties, etc. Thus, it can offer a more favourable transport price per unit of consignment (e.g., ton).

In passenger rail transport, logistics deals in particular with the planning, organization, management and control of all activities between operators entering the transport process, thereby creating the conditions for ensuring safe, reliable, sufficiently fast and convenient passenger transport at the optimum price level in cooperation with other types of transport. The basic strategic objective is to ensure the maximum speed, quality and comfort of the territory with a positive impact on the optimal interconnection of the regions and their economic development. To achieve this goal, the introduction of an integrated transport system, integrating transport and tariff conditions, increasing the coordination of transport modes and co-operation between individual carriers, is the most appropriate solution. The more integrated the transport system is in place, the better for the traveling public, and the logistics of public passenger transport work at a higher level $[3,6]$.

The main tasks of logistics in passenger rail transport are:

- Review of passenger traffic flows at certain times in transport sessions using different survey / marketing methods.

- Optimization and control of these transport streams

- Improving the various factors of the transport process

- Improving the relationship with customers

- Ensuring quality services and optimal travel culture - cleanliness and comfort of the means of transport, seating, technical condition of the vehicle

- Ensuring optimal cost and ease of customer clearance

- Solving the complex logistics chain - road from house to house $[1,7,8]$.

\section{System for quality assessment of rail passenger transport logistics}

Logistics always strives to find the optimal solution for the provision of passenger transport services, with a strong emphasis on quality to the fullest extent possible, as at present the passenger wants not only to dislocate, but he is interested in traveling and demanding a certain level of service. The assessment of the quality of passenger rail transport logistics is a very broad topic and can be viewed from several angles. The most relevant way of assessing quality is the concept examining selected quality indicators in passenger transport, which are a very important and decisive factor for the traveling public. They can 
be divided into quantitative, qualitative and others. These quality indicators form the basis of the proposed methodology for assessing the quality of rail passenger transport logistics. Within the proposed methodology, a scoring scale will be developed for these indicators, which will provide a comprehensive assessment of the quality of passenger transport logistics. In practice, this methodology will be applied and tested for a selected transport routes $[2,9,10]$.

The supporting and decisive indicators are broken down as follows:

- number of connections

- average speed of achievement

- time interval between links

- types of train

- availability of railway stations and stops

- transport distance - coefficient $\gamma$

- transportation services and comfort $[11,12]$.

\subsection{Methodology of scoring and objective evaluation of quality indicators}

In the case of the evaluation of selected quality indicators (factors), the point method of multi-criteria analysis will be used. Indicators with a slightly higher weight can be rated at most by ten points; lower weight factors can rise to eight points. This system of classification on points and the subsequent scale for the evaluation of individual factors was determined by expert estimation and in this way carried out in consultation with selected representatives of a broad professional public. Consequently, an analysis of the evaluation of a certain transport routes will be carried out, which will use the biasing of these indicators. The Bratislava - Sered' route will be chosen transport report for testing the new methodology. Table 1 contains a set of all factors with the maximum possible number of points achieved in the complex evaluation of the transport routes [11]:

Table 1. System for point assessment of quality indicators. Source: [11]

\begin{tabular}{|c|c|}
\hline $\begin{array}{c}\text { Factors influencing on the quality assessment of a particular } \\
\text { transport session : }\end{array}$ & $\begin{array}{c}\text { Maximum achieved } \\
\text { point number: }\end{array}$ \\
\hline Number of connection per day & 10 \\
\hline Average speed of achievement & 10 \\
\hline Average time interval between links & 8 \\
\hline Transport distance coefficient $\gamma$ & 8 \\
\hline Types of train & 8 \\
\hline Starting and finishing station availability & $8(4+4)$ \\
\hline $\begin{array}{c}\text { Detailed information about the services provided in the home, } \\
\text { destination and transit stations }\end{array}$ & 8 \\
\hline SUMMARY: & $\mathbf{6 0}$ \\
\hline
\end{tabular}

From the above data it follows that the maximum possible rating of the selected transport route can be up to 60 points. The final quality evaluation with a point scale, percentage expression and verbal evaluations, according to which the final evaluation of the selected transport routes will be carried out is mentioned in table number $2[5,8]$. 
Table 2. Final assessment for transport routes. Source: [11]

\begin{tabular}{|c|c|c|}
\hline $\begin{array}{c}\text { The amount of } \\
\text { achieved } \\
\text { points: }\end{array}$ & $\begin{array}{c}\text { Percentage } \\
\text { expression: }\end{array}$ & Verbal assessment: \\
\hline $60-49$ & $\mathbf{1 0 0 - 8 1 \%}$ & Green field - the quality of the transport session is excellent, \\
strict criteria are met
\end{tabular}

\subsection{Point assessment for transport routes evaluation}

However, for the implementation of the above-mentioned final evaluation, it is necessary to exactly define a scale for the classification of individual factors for routes evaluation. The more favourable the value of a particular factor, the final score will be higher. This evaluation is shown in Tables 3 and 4.

For the factor, the number of connections per day is considered only with logically and geographically meaningful connections, taking into account that no two connections have the same time to leave the home station or time to arrive at the finishing station. In case of starting and finishing destination availability factor, it is very important to differ starting and finishing station availability separately. In both cases, a maximum of four points can be obtained. For this factor, the scale for city and village is different. However, it is also possible to obtain the "Bonus points" in the case when the high quality and heavy urban mass transportation that runs between the railway station and the centre of the individual settlements is ensured [13-15].

Table 3. Point assessment of selected quality indicators. Source: [11]

\begin{tabular}{|c|c|c|c|c|c|}
\hline $\begin{array}{c}\text { Number of } \\
\text { connection } \\
\text { per day: }\end{array}$ & $\begin{array}{c}\text { Point } \\
\text { assessment: }\end{array}$ & $\begin{array}{c}\text { Starting and } \\
\text { finishing } \\
\text { destination } \\
\text { availability in } \\
\text { villages(km) }\end{array}$ & $\begin{array}{c}\text { Point } \\
\text { assessment: }\end{array}$ & $\begin{array}{c}\text { Starting and } \\
\text { finishing } \\
\text { destination } \\
\text { availability in } \\
\text { cities (km) : }\end{array}$ & $\begin{array}{c}\text { Point } \\
\text { assessment: }\end{array}$ \\
\hline 0 & 0 & 0.4 and less & 4 & 0.6 and less & 4 \\
\hline 1 & 1 & $0.41-0.80$ & 3 & $0.61-1.20$ & 3 \\
\hline 2 & 2 & $0.81-1.20$ & 2 & $1.21-1.80$ & 2 \\
\hline 3 & 3 & $1.21-1.60$ & 1 & $1.81-2.50$ & 1 \\
\hline $4-5$ & 4 & 1.60 and more & 0 & 2.51 and more & 0 \\
\hline $6-7$ & 5 & & & & \\
\hline $8-9$ & 6 & & & & \\
\hline $10-11$ & 7 & & & & \\
\hline $12-14$ & 8 & & & & \\
\hline $15-17$ & 9 & & & & \\
\hline 18 and more & 10 & & & & \\
\hline
\end{tabular}


Table 4. Point assessment of further selected quality indicators. Source: [11]

\begin{tabular}{|c|c|c|c|c|c|}
\hline $\begin{array}{c}\text { Average time } \\
\text { interval } \\
\text { between links } \\
\text { (min): }\end{array}$ & $\begin{array}{c}\text { Point } \\
\text { assessment: }\end{array}$ & $\begin{array}{c}\text { Average } \\
\text { speed of } \\
\text { achievement } \\
\text { (km/h): }\end{array}$ & $\begin{array}{c}\text { Point } \\
\text { assessment: }\end{array}$ & $\begin{array}{c}\text { Transport } \\
\text { distance }- \\
\text { coefficient } \\
\gamma:\end{array}$ & $\begin{array}{c}\text { Point } \\
\text { assessment: }\end{array}$ \\
\hline $0-30$ & 8 & 100 and more & 10 & $1-0.91$ & 8 \\
\hline $31-60$ & 7 & $99-90$ & 9 & $0.90-0.81$ & 7 \\
\hline $61-90$ & 6 & $89-80$ & 8 & $0.80-0.71$ & 6 \\
\hline $91-120$ & 5 & $79-70$ & 7 & $0.70-0.61$ & 5 \\
\hline $121-180$ & 4 & $69-60$ & 6 & $0.60-0.51$ & 4 \\
\hline $181-240$ & 3 & $59-50$ & 5 & $0.50-0.41$ & 3 \\
\hline $241-300$ & 2 & $49-40$ & 4 & $0.40-0.31$ & 2 \\
\hline $300-900$ & 1 & $39-30$ & 3 & $0.30-0.21$ & 1 \\
\hline 900 and more & 0 & $29-20$ & 2 & $0.20-0$ & 0 \\
\hline & & $19-10$ & 1 & & \\
\hline & & $9-0$ & 0 & & \\
\hline
\end{tabular}

In the case of the transport distance factor, a new coefficient $\gamma$ is proposed. This coefficient describes the transport distance deflection, which expresses the advantage of the realization of the selected transport route by rail, is considered. This coefficient calculates the ratio of the air distance of the session and the distance of the transport session by rail. The higher the value of the route, the greater the distance of the transport route along the railway line will be more direct and more suitable for the passengers [16, 17].

For factors train types and detailed information on the services provided at the destination, finish stations and transit stations, it is not possible to set an exact scale for the point assessment. For train types, this rating is based on the combination and number of trains of higher and lower quality. The factor expressing information on services at stations is based on their specific quality and quantity [11].

\subsection{An example of application at transport route}

A practical example of the use of this methodology will be the Bratislava - Sered' transport route (on a working day).

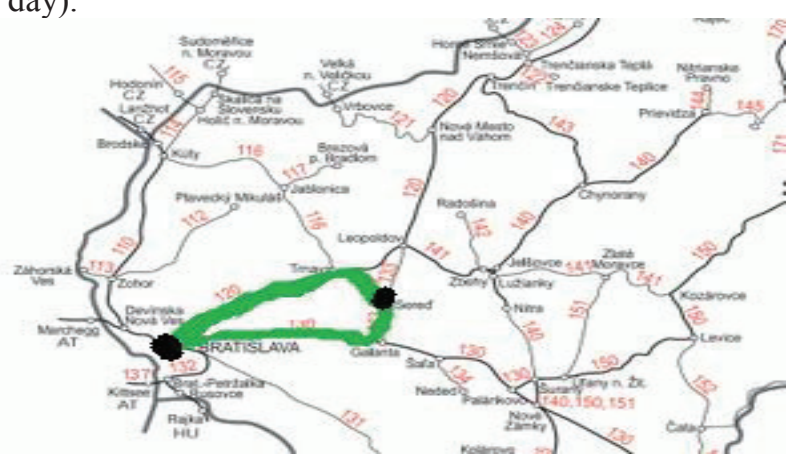

Fig. 1. Illustration of Bratislava - Sered' transport route. Source: [11]

In the case of the train types factor, it can be stated that the transport session can be reached by train with categories $\mathrm{R}$ (fast train), RR (regional fast train) and Os (suburban train). These are middle and lower category trains and based on this statement, the factor will be assigned a half point. In case of availability of station Bratislava hl. st. a bonus point for the above reason, which represents the heavy urban mass transportation in Bratislava, will be added to the point score resulting from the scale. For detailed information about the 
services provided at the Bratislava hl. st., Trnava, Galanta and Sered' can be considered with six points from the eight possible. In the case of the newly introduced coefficient of the transport distance deflection $\gamma$, the value of the air transport distance is $47.5 \mathrm{~km}$ and the distance by rail $61.5 \mathrm{~km}$. The coefficient $\gamma$ will be $47.5 / 61.5=0.77$.

The total score for the transport route will be the same as it is listed in table 5 .

Table 5. Complex point assessment of Bratislava - Sered' route. Source: [11]

\begin{tabular}{|l|c|c|}
\hline $\begin{array}{l}\text { Factors influencing on the quality of a } \\
\text { particular transport relations: }\end{array}$ & $\begin{array}{l}\text { The value adjacent to } \\
\text { the factor: }\end{array}$ & $\begin{array}{l}\text { Achieved point } \\
\text { number according } \\
\text { to scale : }\end{array}$ \\
\hline Number of connection per day & 23 & $\mathbf{1 0}$ \\
\hline Average speed of achievement & $64.06 \mathrm{~km} / \mathrm{h}$ & $\mathbf{6}$ \\
\hline Average time interval between links & $49.09 \mathrm{~min}$ & $\mathbf{6}$ \\
\hline Transport distance - coefficient $\gamma$ & 0.77 & 4 \\
\hline Types of train & - & $\mathbf{3}$ \\
\hline Availability - railway station Bratislava hl. st. & $1.6 \mathrm{~km}$ & $\mathbf{6}$ \\
\hline Availability - railway station Sered' & $1.5 \mathrm{~km}$ & $\mathbf{4 4}$ \\
\hline $\begin{array}{l}\text { Detailed information about the services provided } \\
\text { in the home, destination and transit stations }\end{array}$ & - & $\mathbf{7 3 . 3 3 \%}$ \\
\hline SUMMARY: & & \\
\hline Percentage expression: & & \\
\hline
\end{tabular}

This complex assessment shows that the transport session received 44 points out of 60 possible, representing 73.33 percent of the quality. It means that it can be included in the so-yellow-green field - the quality of the transport route is fairly good, most of the criteria are met [11].

\section{Conclusion}

The proposed methodology for assessing the quality of passenger transport logistics should, in practice, help the infrastructure manager or the transport coordinator in the Integrated Transport System to simplify, more accurately and more readily identify the selected quality indicators and evaluate the transport routes. This will make it easier to discover in the problematic spots in train traffic diagram, which should help to make it better in future years.

At present, quality assessment in the logistics rail passenger transport is not implemented through a comprehensive methodology and the results often do not have the required reporting value, the suggested facts would certainly help to better gauge train traffic diagram quality and thus to help to avoid the introduction of poor quality variants. On this basis, there is a prerequisite for improving the train traffic diagram, linking the different types of transport, increasing the number of passengers, increasing customer satisfaction, as well as a comprehensive improvement and improvement in rail transport that has stagnated in recent years. From the point of view of logistics, this methodology should help to find the optimal alternative for moving people with the maximum synergy effect of selected quality indicators. The main result should be a high-quality logistical chain with satisfied customers $[13,18]$. 
The paper is supported by the VEGA Agency by the Project 1/0095/16 "Assessment of the quality of connections on the transport network as a tool to enhance the competitiveness of public passenger transport system", that is solved at Faculty of Operations and Economics of Transport and Communication, University of Žilina.

This paper is supported by the research project "From horse-drawn railway to intermodal transport" within Visegrad Fund.

\section{References}

1. M. Kendra, M. Babin, P. Šulko, BulTrans-2013 - Anniversary scientific conference on aeroanutics, automative and railway engineering and technologies, 95-97 (Sofia, Bulgaria, 2013)

2. T. Skrúcaný, M. Kendra, M. Škorupa, Procedia Engineering 192, 806-811 (2017)

3. I. Gros, I. Barančík, Z. Čujan, Velká kniha logisitky (Prague, Czech Republic, 2016)

4. M. Šulgan, J. Gnap, J. Majerčák, Postavenie dopravy v logistike (University of Zilina, Slovak Republic, 2008)

5. M. Škorupa, M. Kendra, Procedia Engineering 192, 800-805 (2017)

6. G. Fedorko, V. Molnár, J. Strohmandl, M. Vasil', Transport Means 2015 - 19th international scientific conference, 466-469 (2015)

7. L. Černá, A. Dolinayová, J. Daniš, Transport means 2016 - 20th international scientific conference, 414-419 (Juodkrante, Lithuania, 2016)

8. L. Černá, V. Zitrický, J. Daniš, Open Engineering 7, 6-13 (2017)

9. J. Mašek, M. Kendra, J. Čamaj, Transport means 2016 - 20th international scientific conference, 584-588 (Juodkrante, Lithuania, 2016)

10. E. Majerčáková, P. Majerčák, Logi - Scientific Journal on Transport and Logistics 6, 1, 90-99 (2015)

11. M. Dedik, Connection quality assessment in the railway transport from the railway network aspect (Diploma thesis, University of Zilina, Slovak Republic, 2016)

12. G. Fedorko, H. Neradilova, M. Sutak, V. Molnar, Transport means 2016 - 20th international scientific conference, 169-174 (Juodkrante, Lithuania, 2016)

13. M. Chovancova, V. Klapita, Transport means 2016 - 20th international scientific conference, 112-116 (Juodkrante, Lithuania, 2016)

14. R. Kampf, L. Ližbetinová, K. Tislerová, Open Engineering 7, 26-30 (2017)

15. P. Majerčák, E. Majerčáková, Transport means 2016 - 20th international scientific conference, 688-692 (Juodkrante, Lithuania, 2016)

16. Euroekonom.sk - Diplomova_teoria_obchod, Available online: http://www.euroekonom.sk/download2/diplomovka-teoria-obchod/Teoria-Diplomovapraca-Logistika-predmet-a-obsah-logistiky.pdf (2017)

17. V. Lendel, M. Varmus, Logi - Scientific Journal on Transport and Logistics 3, 2, 2134 (2012)

18. O. Stopka, I. Simkova, V. Konecny, Nase More 62, 3, 126-130 (2015), DOI: $10.17818 / \mathrm{NM} / 2015 / \mathrm{SI} 7$ 